\title{
PRIMARY DIAMOND SOURCES IN FRENCH GUIANA: IMPLICATIONS FOR TRANSAMAZONIAN GEODYNAMICS AND DIAMOND EXPLORATION
}

\author{
RAMON CAPDEVILA $^{1}$, BERTRAND TAQUET ${ }^{2} \&$ CARLOS BERTONI $^{2}$
}

Boreholes carried out in 1995 by Guyanor Ressources SA in the Dachine region (Transamazonian Inini Greenstone Belt, South French Guiana) have cut through talcschists rich in microdiamonds. The most common mineral assemblage of these rocks is: "talc + chlorite \pm tremolite \pm carbonate". These minerals can be often accompanied by albite, serpentine, stilpnomelane or phlogopite. The volcanoclastic texture of the protolith is preserved despite metamorphism and deformation. Even scoria fragments are preserved in places. Diamonds, accompanied by eclogitic and mantle indicators, are present as xenocrysts. They are of eclogitic type, the timespan of their residence in mantle conditions is $<200,000$ years and they were transported in a magma characterised by a high $\mathrm{H}_{2} \mathrm{O} / \mathrm{CO}_{2}$ ratio. The diamonds formed therefore only a short time before the komatiitic magmas.

The mobile element composition of the talcschists is variable. They were first slightly modified during greenschist facies metamorphism. Later, they were locally hydrothermally altered in the surroundings of late- to post-orogenic intrusions. Finally, they were subject, to various degrees, to tropical alteration. On the other hand, the immobile element composition is constant and allows an unequivocal identification of the protolith. This chemical composition coincides with that of Ti-rich Al-depleted komatiites (Karasjok-type). The Aldepleted character implies an origin of the primary magmas by partial melting of a garnet-bearing mantle source at depths > $250 \mathrm{~km}$ and under anhydrous conditions.

These komatiites are common in the Inini Greenstone Belt, where they form layers or lenses up to several hundreds of meters thick and stretching over more than $200 \mathrm{~km}$, from the Eastern to the Western border of French Guiana. These komatiites, sometimes accompanied by tholeiites and $\mathrm{Mg}$ basalts, are interstratified at various levels with an arc sequence that ranges from calc-alkaline basalts to rhyolites and that ends with graywacke sediments. The geochemical and isotopic properties of the volcanic rocks of this sequence are these of a primitive island arc.

The Inini Greenstone Belt results therefore from a plume/ arc interaction. The presence of a subduction zone formed a screen for the mantle plume and inhibited the formation of a plateau of tholeiites and komatiites on the surface. It could not, however, prevent the hottest liquids of the plume from repeatedly passing through. When these dry komatiitic liquids entered into contact with the oceanic slab and the relatively cool and hydrated mantle wedge, they became enriched in water and incompatible elements and rose quickly towards the surface while taking along xenocrysts and diamond-bearing xenoliths.

Diamond exploration should note that in the case of the south of French Guiana the Clifford rule does not apply and alluvial diamonds are accompanied by komatiitic (e.g. spinels) rather than kimberlitic indicators. Fertile komatiites must obligatorily be volcanoclastic and of Karasjok-type, which appears to be very rare so far. However, they should occur in West Africa.
I Géosciences Rennes, Université Rennes I, 35042 Rennes Cedex, France

2 Guyanor Ressources SA, BP750, 97337, Cayenne, Guyane
Manuscrito NB-46 Recebido em 15 de novembro de 2001 Revisão dos autores em 30 de novembro de 2001 Revisão aceita em 01 de dezembro de 2001 